\title{
Public Management at the Ballot Box: Performance Information and Electoral Support for Incumbent English Local Governments
}

Oliver James

University of Exeter

Peter John

University of Manchester

\begin{abstract}
Publishing performance information about local public services, an increasing trend in many Organisation for Economic Co-operation and Development countries, matters politically because it has an effect on incumbent local governments' electoral support. Voters are able to use performance information to punish or reward incumbents in the elections that follow their publication, which may fill a gap in the chain of accountability between voters and governments. We model the introduction of published Comprehensive Performance Assessments of local authorities in England, which make summary information about performance available to voters, as a "shock" to the relationship between voters and incumbents. Controlling for an unpublicized measure of performance change over time, change in the local tax level, change in local economic conditions, and whether the local incumbent is the party of the incumbent government at the national level, we find negativity bias. Incumbents in local authorities in the "poor" performance category experience a substantial reduction in aggregate vote share at the election following publication, but there is no similarly sized reward for those in the highest performance category.
\end{abstract}

This article examines the political consequences of the publication of information about the performance of local public services, focusing on change in electoral support for incumbent local governments. The topic is important because much of the effective practice of a democracy depends on the existence of a link between the citizens and decisions taken by public bureaucracies in their name (Jones and McDermott 2004; Key 1966; Ranney 1954). If citizens attempt to update their views of an incumbent government with information about how well it is running the services and activities under its control, they need accurate information to make judgments about the agents who are supposed to be doing their bidding. Policy makers in many Organisation for Economic Co-operation and Development (OECD) countries have made considerable investment in performance measurement systems in

Address correspondence to the author at o.james@exeter.ac.uk. 
recent years, including systems that publish information intended for consumption by citizens and users (Hood et al. 1999, 2004; Pollitt and Bouckaert 2004). Most of the evaluation of such systems directs attention to the efficiency and effectiveness of bureaucracies and policy making rather than to the wider political arena. The connection between public management and political behavior has been largely neglected because the literatures have mostly been developed as separate areas of endeavor; this article seeks to fill this gap.

An opportunity for a first assessment of the political consequences of introducing a regime of published performance measures has been created by the introduction of Comprehensive Performance Assessments (CPAs) of local governments in England. The CPA system can be seen as a "shock" to existing voter-government relationships as it creates a rigorous, public performance measurement for the whole of English local government. The bodies subject to the regime are also subject to direct election, offering the opportunity to assess the electoral consequences of the introduction of the regime for incumbent local governments alongside other factors conventionally seen as influential on their support.

\section{ELECTIONS AND INFORMATION ABOUT GOVERNMENTS' PERFORMANCE}

The control of elected representatives through voting is one of the enduring themes of the theory of representative democracy, which posits that citizens transmit their preferences into policy choices by casting their votes. In the classic model of responsible party government (Jones and McDermott 2004; Ranney 1954), electors hold the party in control of the executive and/or the legislature to account, based on their judgments of performance and alternatives available to them (which may use retrospective or prospective assessments or some combination of the two). The "responsibility hypothesis"—also called the "reward-punish" hypothesis — suggests that if governments perform badly or depart from their promises or voters shift their position without a corresponding change in the government's policies, voters may "vote the rascals out" in a time-honored fashion and call in a new administration to effect their preferences.

It is often suggested that voters often do not have the levels of information necessary to judge the performance of an incumbent government (Delli Carpini and Keeter 1996, 79-82; Iyengar 1987; Milner 2002, 27). Information is needed to support democratic choices and, in extreme cases, a lack of information could break the chain of electoral accountability, making much of the rest of the practice of democracy redundant. However, in the main areas where citizen-policy performance links have been investigated, especially economic voting, research finds that many aspects of representative democracy do work in practice (Clarke et al. 2004; der Brug, van der Eijk, and Franklin 2007; Lewis-Beck and Paldam 2000; Sanders 2000; Wlezien 2004). Incumbent elected agents are often held responsible for macroeconomic performance and rewarded or punished in proportion to these levels or changes in these levels. A tradition of research and theory, going back at least as far as Downs (1957), suggests that voters economize on information by looking for cues to determine their action rather than making detailed assessments. Even though voters lack knowledge about the detail of changes in particular variables in the economy, they are still able to make informed judgments about the behavior of office holders to judge incumbents on economic performance (see Jacobson 1990; Kramer 1971; Lewis-Beck and Paldam 2000; MacKuen, Erikson, and Stimson 1992).

The role of information about performance of government services in electoral support for incumbents has particular relevance because of recent New Public Management (NPM) reforms. In part, NPM has involved increasingly sophisticated attempts to measure 
outputs and outcomes of public sector activity, measures validated by third-party auditors and inspectors that do not rely on service providers or users, although performance measures have a long history before this time and users and service producers normally have some role in their production. The trend is occurring in many OECD countries (Hood et al. 2004; Pollitt and Bouckaert 2004). For example, there have been major investments in the United Kingdom including systems for the "executive" parts of the civil service reorganized into "agencies," the National Health Service, and local government (Boyne 1998; Hood et al. 1999; James 2003, 2004; Pollitt, Birchall, and Putnam 1998). In the United States, the Government Performance and Results Act has mandated systems for Federal Government; systems have also been developed in most state and local governments (Melkers and Willoughby 1998; Moynihan 2005; Radin 1998).

When performance information is published, the measures of performance offer the potential better to inform citizens and service users about their quality. This information potentially supplements citizens' and users' own direct experiences and sources such as word of mouth or information provided by local public bodies themselves. The information may influence political participation, including how people vote. Of course, published information might influence citizens' actions in ways other than voting. At least two forms and their hybrid are commonly suggested. First, choice of provider by service users is typically taken as involving them choosing services that provide desired outcomes (often using a calculation involving costs and benefits with a consideration of the transaction costs involved in exercising choice). In this activity, information about performance is key in decision making and exercising choice which often involves "exit" from one provider and "entry" to another (perhaps by geographical movement by the household between different local government units). A second set of activities are often grouped together and labeled "voice" processes, in which various means of expression such as lobbying, voting, and protest reflect satisfaction or dissatisfaction with public services. There is a sizeable literature examining exit and voice processes and their outcomes (see John, Dowding, and Biggs 1995; Lyons and Lowery 1989; Tiebout 1956).

English local government offers an appropriate laboratory for exploring the publication effect on election outcomes. Although the systems of performance measures have developed piecemeal for many years, the sophistication of measures has increased recently with measures of performance covering each service sector. Crucially for our analysis, the establishment of the CPA regime was a major step change (Department for Transport Local Government and the Regions 2001). The regime was made operational in 2002 and is run by the Audit Commission, an independent public body. It brings together a bundle of measures of local government performance in an overall assessment of service performance and management competence for each authority unit (Audit Commission 2002; Broadbent 2003). The services principally include education, social services, refuse collection, leisure, and local environmental services. The scores for different service areas would in principle enable an analysis by each sector. However, we limit ourselves to the "overall" CPA effect primarily because the assessment of the local authority in overall terms is the published piece of information given prominence in the regime. Individual service sector scores, although available, are not so directly accessible. The CPA established, for the first time, a published performance score and a categorization of each local authority in one of five categories of "excellent," "good," "fair," "weak," or "poor" performance. Contemporary policy makers express the hope that this sort of regime is useful for citizens to inform their political actions (Cabinet Office 1999; Performance and Innovation Unit 2001, 22-3). 
There are good reasons to think that information about the performance of local public services, such as that found in the CPA, is more likely to influence support for incumbents in England relative to similar relationships in other contexts (especially national or regional level government). It is often hard for citizens to observe accurately the marginal adjustments in the aggregates of employment, inflation, and economic activity that result from policy instruments rather than the international economy and from autonomous domestic investment and consumption decisions. By contrast, local public bureaucracies delivering public services might be expected to be under more direct control by politicians, with citizens more justifiably holding politicians to account for their performance. These local-level bodies are often more limited in the range of services they provide than national, regional, or state governments, with their activities established and run under laws and executive commands with regular public financing and oversight. The English local government consists of units that are near exclusively responsible for providing a set of nationally prescribed local public services and little else. The overwhelming majority of expenditure is on mandated services, and there are statutory limitations and financial disincentives to providing other services. Although party competition feeds into slightly different policy outputs at the local level (Boyne 1998, 61-90), these effects are much less significant than those at higher levels of government. The English local electoral system can promote a strong link between voting and rewarding or punishing incumbents because there is usually a party in control of the administration. It is a first-past-the-postelection system, and the election mechanism within each electoral district or ward is reasonably clear. On these arguments, citizens may be more likely to take information about performance into account as a significant influence when voting in this context than in other elections.

\section{MODELING THE IMPACT OF THE CPA PERFORMANCE INFORMATION REGIME}

The CPA may potentially have an impact because it is a cue that voters can use to summarize a lot of information about their local authority in a simple and cost-effective way. Furthermore, the CPA contains both an assessment of past performance and an assessment of local authorities' capacities which provides information about the likely future performance of services. The CPA system would seem to meet the criteria for successful use of information cues that have emerged in research on the acquisition and use of information by voters (Aidt 2000, 365; Lupia and McCubbins 1998, 4-11). The CPA is likely to be more trusted than information coming from the service provider directly. The Audit Commission is formally independent of local authorities and has produced a number of reports that are highly critical of aspects of performance. The CPA information is potentially of additional use in making other decisions, such as exiting to another jurisdiction, which might increase the incentive for individuals to acquire it.

We model the publication of performance information in the CPA as a shock to the system by potentially providing information about local government not previously available to voters. This approach does not necessarily suggest that the CPA information is a fully reliable measure of performance (although the auditors and inspectors constructing the system claim they are striving to achieve this), but instead that the publication of performance information may have an effect. We hypothesize that this shock will be reflected in change in the percentage shares of the vote for incumbent local governments in the elections following its introduction from that they received in the elections prior to the CPA. If such performance was already known to voters, it might reasonably be 
expected already to be included in the previous level of electoral support for incumbents before the establishment of the CPA regime, and if the new CPA information is not relevant to voters, then it would not be expected to result in a change in support either.

The literature on use of information in elections suggests different ways in which the influence of publication might operate, so we examine three models to evaluate these possibilities. In the first model, we examine the hypothesis that a quantitative CPA score (with scores potentially in the range 0-60) influenced electoral support. These scores were published as part of a summary report on each local authority. Figure 1 shows the simple bivariate relationship between CPA score and change in incumbent's percentage share of the vote between 1999 and 2003. At first sight, a slight positive linear relationship is apparent, but such a description does not include control variables. The key hypothesis for the multivariate model from this version of the CPA effect is that higher scores will be associated with higher changes in incumbent support in a straightforward linear relationship.

In the second and third models, we draw on the insight that information about extremes in performance has been shown to be more influential on elections than information about middle ranges; for example, voters generally react to more extreme changes in the economy (Palmer and Whitten 1999). To do this we examine the categories in the CPA (poor, weak, fair, good, and excellent) that potentially give a stronger cue than the continuous score for cases in the extreme categories. In the second model we assess the effect of CPA categories using a set of dummy variables by contrasting good and excellent performers with poor and weak performers, with fair as the reference category. The third model contains the top and bottom categories of score, CPA excellent and CPA poor, respectively, with the scores in the middle categories as a reference group to see if there was an effect associated with distinguishing the very best or worst performers. The simple bivariate relationship between the CPA categories and change in an incumbent's percentage share of the vote is shown in figure 2. Of the 47 local authorities, 4 (9\%) were rated excellent, $18(38 \%)$ were rated good, $12(26 \%)$ fair, $8(17 \%)$ weak, and $5(11 \%)$ poor (the lowest category). CPA poor has a lower mean value for change in vote $(-11.1 \%)$ than each of the other categories. Key hypotheses for the second and third models in the multivariate modeling are that substantively important, significant, influences on support are found rewarding the categories above the middle range and punishing performance below this level.

The second and third models enable the possibility of asymmetry in response to the information in the categories, particularly the possibility of negativity bias. Negativity bias entails greater weight of negative information relative to equally strong positive information in information processing and political outcomes. It has previously been found in a range of contexts, notably political perceptions of candidates (Lau 1982, 1985), public opinion (Soroka 2006), and economic voting. In economic voting at the aggregate level, the results are mixed; studies have found that negativity bias among voters who are economic losers is sometimes offset by these economic losers not turning out to vote, reducing the aggregate effect on electoral outcomes (Radcliffe 1994; Rosenstone 1982). In contrast, it would seem that there might be good reasons for negativity bias in electoral outcomes in the context of the CPA for local government. All voters are exposed, if differentially, to the overall services provided by the local authority and so, for example, would be losers from poor performance.

In each of the three models, we examine the change in percentage of support for incumbents between the elections of 1999 and 2003 (Rallings and Thrasher 1999-2003). With the exception of cases of minority administrations and no overall control, there is an incumbent party in command. The elections in May 2003 were held for all metropolitan boroughs and 


\section{Figure 1}

CPA Score and Change in Percent Support for Incumbent

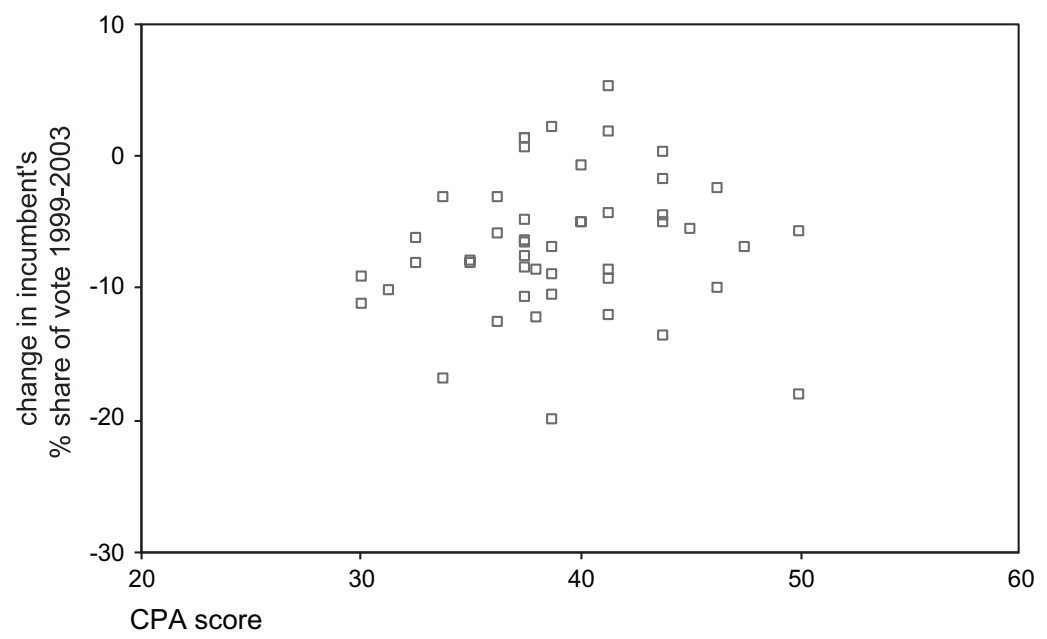

unitary authorities. ${ }^{1}$ We exclude cases where no party had overall control of the local government, so the electorate could clearly identify which group of politicians were responsible for performance; in all cases, one of the three main UK political parties was incumbent.

The key question for the analysis whether CPA influences electoral support even after the other factors which also influence such support are taken into account. To address this question we explore the relationship between the three formulations of the CPA variable and change in electoral support. As part of the analysis, we model an alternative possible influence - that the performance of local authorities might have changed between the two elections driving a change in electoral support. We include a measure of each local authority's change in overall performance as a percentage of the authority's base level of performance in 2000. The score is calculated by aggregating "Best Value" and other indicators for different service areas weighted by expenditure in that area. ${ }^{2}$ Although some of the component parts of the index are occasionally published in other reports, the overall pattern of performance is not generally accessible to citizens, so it is an unpublicized

1 There is no reason to think that the authorities holding elections at this time differ from those of the same type holding elections at other times, beyond the obvious difference in the timing of the election. While some councils elect by thirds, so that there were other elections between 1999 and 2003, 1999 is used as a base year for simplicity. We ran a separate regression for the 37 cases electing by thirds which produced the same significance levels and similar coefficients for the variables reported in table 1, a separate regression for cases of whole-council elections was not possible because of the small number of cases, and ideally, the results presented here should be further explored using larger data sets.

2 The indicators were chosen to cover the full range of key services, namely, education, social services, housing, benefits delivery, local transport, planning, culture, community safety, and waste services. They include all available measures for service areas for the period (BV3, BV8, BV9-10, BV12-16; BV34a-b; BV38-9, BV45-6, BV49-50, BV535, BV58, BV52-4, BV66a, BV72-4, BV78a-c, BV79a, BV82, BV96-7, BV99a-e, BV100, BV102, BV104-6, BV109, BV111, BV117, BV126, BV129, BV170, BV179, BV162, PAFA3, PAFB7, PAFC19, PAFC21, PAFC24, PAFE49, 61/ BV59, DFES5M, DFES5E). The average scores for indicators in each service block were calculated, and these results were weighted according to expenditure to give an overall score for each local authority. These scores were then compared to the average for all local authorities in 2000 to score each local authority as a percentage of this average in both 2000 and 2003. The difference between these two scores as a percentage of the 2000 score was then used as a measure of performance change, on the basis that performance change as a percentage of base-level performance would be likely to be most noticeable to citizens/voters in a local area. 
Figure 2

CPA Categories and Change in Percent Support for Incumbent

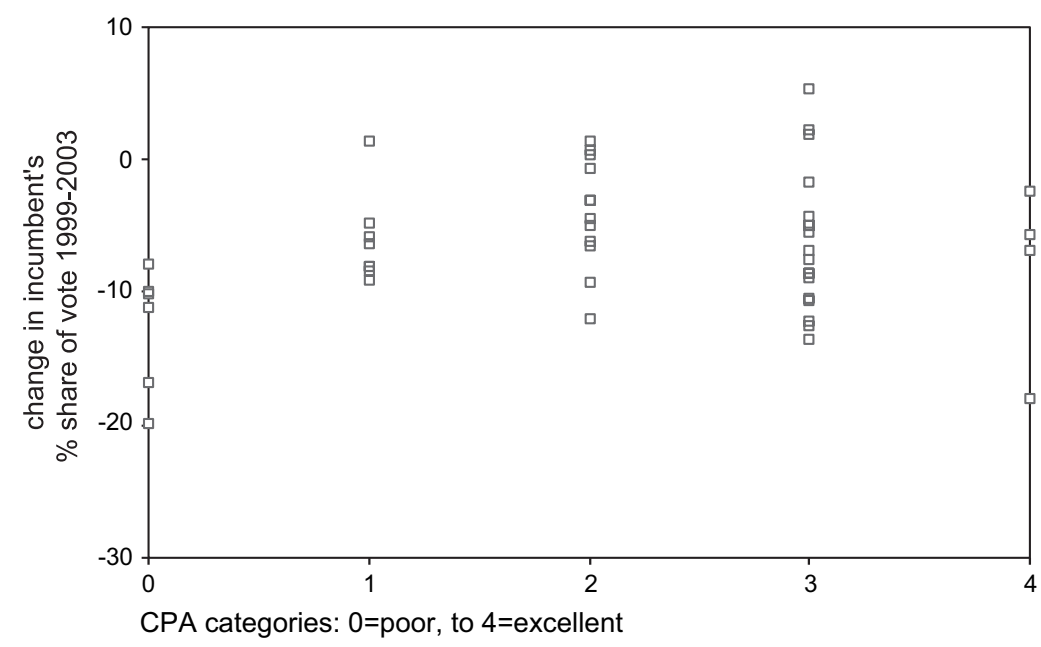

measure. This variable is not the same as the static published CPA score or categories which might otherwise make it difficult to assess the separate effect of the introduction of the CPA. In our analysis, if the coefficient for the nonpublic measure were to be significant and positive, it would provide some support to the responsibility hypothesis for performance in the form that change in performance is observed directly by citizens (e.g., by word of mouth or direct experience). If the coefficient for the published CPA score were, in the same analysis, to be significant and positive, this would suggest evidence of a positive CPA publication effect in addition to the effect of performance change over time.

We analyzed media coverage of CPA scores to assess if the amount and nature of coverage was related to change in support. We derived a media effect variable from a comprehensive survey of national newspaper reporting of the CPA scores during the period between publication of the score and the election. We focused on national coverage because of the importance of national newspapers in England which has, by comparison with most other nations, unusually high readership across all areas of the country. There are 19 titles with fully national circulation, and they are conventionally viewed as a major source of information for voters in electoral politics (Tunstall 1996). In contrast, local newspapers contain a high degree of nonnews-focused material, and the more traditional titles have been in long-term decline (Franklin and Murphy 1998, 10). A major study of local elections in Britain noted national newspapers' coverage of local issues and local elections and that coverage has been increasing in recent decades (Rallings and Thrasher 1997, 208-9). The CPA was of particular interest to the national press because it adopted a standard format for assessing local authorities throughout England, making it nationally newsworthy. In our analysis, each article relating to the CPA of a local authority was coded as providing either a positive or negative assessment of the individual local authority's performance and a "net positive stories" score was calculated (positive stories minus negative stories). ${ }^{3}$ The survey of the press suggested that the CPA results were reported straightforwardly, in the sense of

3 The articles were gathered from full-text analysis of the full texts of articles from the "National Newspapers" archive on the LexisNexis Professional database discussing individual local authorities' CPA results in the period June 2002-May 2003. 
high scores leading to positive stories and low scores leading to negative stories, with the net score providing an indicator of the overall tone of coverage for each authority.

The English local electoral system is not fully distinct from broader national politics. The local parties are largely locally organized, for example, in terms of selection of candidates, but run under the banner and regulation of the national party organization. Voters' opinions about national government has strong effects on local incumbents, with unpopularity conventionally seen as having a negative impact on the local party if it is the same as the national incumbent party and a positive impact if the local incumbent is not of the national party. However, at the same time as evidence of local elections as opinion polls about national government, there is evidence that local voters are capable of making judgments about the local incumbents (Rallings and Thrasher 1997). So we create a dummy variable to indicate Labour councils in the data set as the incumbent national governing party since 1997.

The fiscal profile of the local government unit may be an influence on local elections. Research on the US (Lowry, Alt, and Feree 1998; Niemi, Stanley, and Vogel 1995) finds the voters hold governors to account for the level of state taxes, although the evidence is not clear-cut (Glaser and Hildreth 1996). Martinussen (2004) finds support for local economic and fiscal voting in Norway. In England, some argue that voters punish government with high taxation rates while others claim that the public has a redistributionalist point of view (Hall and Preston 2000). The relationship between local tax and local expenditure is further complicated because grants from central to local government are a very important source of revenue. The last factor makes it hard to create an accountability relationship for subnational bodies as the Conservative found to their cost in 1990, where voters were unable to see the link between local spending decisions and the massive hike in their local tax bills as a result of the introduction of the individual person tax in 1990-1993, the Poll Tax (see Butler, Adonis, and Travers 1994). However, Gibson has challenged the conventional wisdom that local taxes do not affect voting behavior (Gibson 1988, 1994). Because of the debate about this issue, we include a measure of change in the local tax in our analysis, using change in Council Tax levels for Band D ("average") households between 2000 and 2003 (in pounds). The hypothesis is that electors will punish councils for increases and reward them for decreases. Following the economic voting literature, we create a variable that reflects change in local economic conditions. Although there are many different indicators, we focus on change in the number of claimants (those on job seekers allowance) as a proportion of the working-age population in 2000 and 2003 obtained from the Labour Market Statistics of UK National Statistics.

\section{RESULTS: NEGATIVITY BIAS AND THE CPA}

The poor CPA category score appears to be, by a clear margin, the most influential part of the CPA regime. In model 3 , incumbents with a poor CPA suffer a $6 \%$ loss of support compared to those in the reference category (weak, fair, and good CPA results). The full findings for the three models are summarized in table $1 .{ }^{4}$ The more fine-grained CPA

\footnotetext{
4 For completeness, we explored whether a single case or a few cases had a big impact on the results, perhaps warranting respecification of the models, using the DFFITS test of difference in fits for the dependent variable and DFBETA test of the difference in beta values for each independent variable. The results suggested no need to respecify, for example, by using robust regression. We also examined differences between "metropolitan boroughs" operating in largely urban areas and "unitary authorities" operating in a variety of urban and less urban contexts using a dummy variable and found no difference between the groups.
} 
Table 1

Modeling Change in Incumbents' Percentage of Vote Share between 1999 and 2003: Unstandardised Coefficients (with standard errors)

\begin{tabular}{lccc}
\hline & Model 1 & Model 2 & Model 3 \\
\hline $\begin{array}{l}\text { National incumbent } \\
\text { Performance change (unpublicized }\end{array}$ & $-6.96^{* *}(1.44)$ & $-6.43^{* *}(1.48)$ & $-7.01^{* *}(1.31)$ \\
$\quad$ measure) & $0.00(0.02)$ & $0.00(0.02)$ & $0.00(0.02)$ \\
Council Tax change & $0.00(0.01)$ & $0.00(0.01)$ & $0.01(0.01)$ \\
Claimant rate change & $0.79(1.02)$ & $0.81(1.00)$ & $0.30(0.91)$ \\
CPA aggregate score & $0.14(0.14)$ & & \\
CPA excellent or good & & $-1.31(1.47)$ & \\
CPA poor or weak & & $-2.65(1.67)$ & $-6.06^{*}(1.88)$ \\
CPA poor & & & $-1.81(2.50)$ \\
CPA excellent & & & $-1.35(1.18)$ \\
National newspaper reporting of CPA & $-0.93(1.15)$ & $-0.70(1.08)$ & $-0.85(1.72)$ \\
$\quad$ net positive stories score) & $-6.07(5.70)$ & $0.17(2.02)$ & 0.55 \\
Constant & 0.43 & 0.45 & 0.47 \\
$R^{2}$ & 0.34 & 0.35 & $6.74 * *$ \\
Adjusted $R^{2}$ & $4.99^{* *}$ & $4.55^{* *}$ & 47 \\
$F$ & 47 & 47 & \\
$N$ & $47 *$ & &
\end{tabular}

performance scores (with a larger range of values than the five ordered categories) that are examined in model 1 seem not to have had an effect. We also examined nonlinear versions of the CPA score variable, but these were not significant. In addition, the CPA poor and weak, and good or excellent, combined categories in model 2 are not significant, leaving poor CPA performance in model 3 as the key influence. There is clear evidence of negativity bias in the response to the extreme category scores. While the poor CPA has a clear impact, the excellent CPA category is not significant, suggesting that poor performance is punished but equally strong (in terms of absolute difference in level of category from the middle fair category) excellent performance is not rewarded.

There is no support for the hypothesis that councils are rewarded for improvements in performance over time or punished for deterioration, as revealed by the unpublicized measure of performance change included in all three models. Only published CPA poor performance seems to be reflected in electoral punishment. While publication of CPA mattered, the survey of national media coverage did not uncover additional effects that were statistically significant. However, this variable perhaps underplays the influence of the media by categorizing stories as either positive or negative and using a net positive score. It could be that strongly negative stories are the most important influence, and this perhaps contributes to the size of the negative coefficient for the CPA poor variable.

To examine the robustness of the findings, we considered the possibility of a closely related CPA publication effect through an alternative dependent variable - change in an incumbent's share of vote as a percentage of the incumbent's initial vote share. This variant seems likely to be a potentially important way to think about possible effects of performance information; incumbents with smaller initial vote shares might be at a greater risk of "punishment," for example, through their support falling below some threshold triggering loss of control of the council, and people might even be expected to be more 
likely to punish incumbents with smaller shares because of a feeling that they might be more likely to make a difference to the control of the council under these circumstance. This relative importance is captured in the alternative specification of the dependent variable. In this specification, a $5 \%$ fall in a $40 \%$ vote share is a 12.5 change, whereas a $5 \%$ fall in an $80 \%$ share is only a 6.25 change. However, applying this characterization of change produced very similar results. Most notably, in the analogue of model 3, the same variables were significant, with coefficients of $-15.22(p<0.001)$ for national incumbent party and $-11.403(p<0.01)$ for the CPA poor category. These findings suggest that the results for CPA effects are robust to this alternative definition of change in support for incumbents.

Our findings contradict claims that local elections in England are largely "irrelevant" as contests in their own right about local issues (Miller 1988). Instead, they lend support to the position that both local and national issues need to be taken into account (Rallings, Thrasher, and Denver 2005). National incumbency is an important influence on change in electoral support; the variable has a coefficient of between -6.43 and $-7.01(p<0.001)$, with damage to the percentage of support of local Labour party incumbents evident in all three models. The relative importance of national incumbency is also clearly evident, with the standardized coefficients larger than those for the other significant variables. ${ }^{5}$ Despite this finding, although national politics appears to be the single biggest influence on local elections, a published poor CPA performance judgment also matters.

In contrast to the results for the CPA and national incumbency, there does not appear to be local voting on change in level of Council Tax, nor in an alternative specification of percentage of change in Council Tax. Change in local tax may be seen as an issue for national government, perhaps because voters are aware that many of the resources for local government come from the central administration and the level of local tax is partly affected by policy decisions and socioeconomic factors beyond the control of local incumbents. We found no evidence of local economic voting, perhaps because voters are aware of the limited influence local authorities are able to exert on outcomes such as the rate of social security claimants. Recently, research has even suggested that CPA scores are adversely influenced by poor local socioeconomic circumstances (Andrews et al. 2005). In the light of this possibility, we conducted a limited analysis (because of the small number of cases in some categories) to see if local voters appeared to give incumbents the benefit of poor socioeconomic circumstances as a mitigating factor in getting a poor CPA score, reducing the electoral penalty. However, our results suggest that poorly performing local authorities in socioeconomically disadvantaged areas were not blamed less than those in other areas.

Our primary interest is in the published performance information effect on incumbents in terms of change in share of the vote. However, the effect on share of seats and incumbents' control of local authorities shows closely related political consequences of the CPA. We do not seek to model this effect fully, in part because of the complicated systems for transforming vote share into seats and control of the local authority. However, two of the five incumbents with a poor CPA score lost control, in both cases involving a Labour administration falling to a situation of no party having overall control. This situation compared to a loss of control in just 10 of 42 other authorities. Furthermore, an analysis

5 In model 3, CPA poor has a standardized coefficient of -0.38 (smaller than the -0.62 for national incumbency). In the version of model 3 using the alternative definition of change in incumbents' support as a percentage of their initial support, the standardized coefficient for national incumbency was -0.66 and for poor CPA it was -0.35 . 
of eight local authorities that got a CPA poor score in 2002 (including some that did not have elections in 2003) reveals that all experienced some form of major political change in the year following the CPA result. Of the cases that did not suffer loss of control following elections, all had some form of substantial change in their leadership teams including four with new political leaders. The poor CPA result was cited by participants as an important influence on the changes in all except two cases (Turner et al. 2004, 22). Although the study does not systematically compare these cases with political change in local authorities where the CPA result was not poor, the scale and scope of change was greater than was generally found in the sector during the period.

\section{CONCLUSION}

This article brings together research on performance measures and political participation. The realm of influence of performance information extends to the voters who elect local administrations, giving them information so they may make judgments and reward and punish them accordingly. With the performance information of the CPA in their hands, local voters in England were able to deal a blow to incumbents placed in the poor CPA category. The relationship between CPA performance and support for incumbents exhibited clear negativity bias, with the category of poor performance resulting in punishment but excellent performance not being equally rewarded.

Despite the strong influence of national politics on local elections, the findings about CPA suggest that performance-orientated voting should not be viewed as confined to the economy or tax or to the national level. In some ways the CPA can be seen as a more plausible set of measures for voters to use in performance-oriented voting than in these other contexts where even more complex judgments about outcomes and responsibility are required. Even in local government, the concentration of voters' action on cases of poor performance suggests that they are not willing to act on the basis of other grades of assessment.

The effect of naming and shaming involving the revelation of information about poor performers places considerable responsibility on those who produce and communicate such assessments. If the disproportionate response to a poor score in electoral support is also reflected in general attitudes to public services, such as willingness to pay taxes to fund them or to be involved in local coproduction activities such as local committee involvement, it could be that publication has detrimental effects on political participation. Coupled with the finding that citizens did not seem to give poor performers leeway because of the disadvantaged socioeconomic context, which has been demonstrated to be an important influence on service outcomes, this issue could be most profound in the areas where public services are the most difficult to provide.

For electoral accountability to work more fully on an ongoing basis, not only do the electorate need to notice or be told about performance but also they need to act and politicians and bureaucrats need to respond, for example, to regain votes or to form alternative administration. Then citizens need to assess again whether performance has improved or not and then to cast their votes accordingly. There appear to be several factors influencing these relationships that merit further analysis, and similar factors are noted as important in the literature on economic voting (Lewis-Beck and Paldam 2000; Sanders 2000; Wlezien 2004). Although we focused on a sector with relatively simple systems, the degree of party competition may affect the degree to which incumbents are punished with, 
perhaps, two-party systems offering the strongest circumstances for rewarding or punishing the incumbent.

Our analysis is at the aggregate level, but future research might seek to undertake individual-level analysis to explore differential effects, for example, between heavy service users and lighter users (in terms of intensity, frequency, or range of services) and the likelihood of turnout. Poor performance may both make heavy users more likely to vote against local incumbents than light users and make them more likely to turnout to vote in the first place (because other voters may be less concerned about exercising voice relating to performance), compounding the effect. In addition, hypotheses from the two main explanations of negativity bias in political behavior would also seem to merit further research at the individual level. First, individuals may perceive a poor CPA score as incurring greater cost (or disbenefit) than the benefit from an excellent score above the middle range of performance scores, perhaps because they see a poor score as entailing failure to provide a service above a minimum threshold level of performance. Second, comparative, yardstick, performance may be an important influence on individuals' assessments of local authorities. The poor label may have greater salience if it is seen as being further below some notion of average (perhaps mean or median) local authority performance than excellent is above such an average. Combinations of these hypotheses are also possible, for example, with the performance of other local authorities setting what is seen as an acceptable threshold. The punishment for being poor may become greater if fewer local authorities are placed in this category over time.

\section{APPENDIX}

Table A1

Descriptions of Variables Used in Modeling Change in Incumbents' Percentage of Vote Share between 1999 and 2003

\begin{tabular}{lccrr}
\hline \multicolumn{1}{c}{ Variable } & Minimum & Maximum & Mean & SD \\
\hline $\begin{array}{l}\text { Change in incumbent percent share } \\
\text { of vote (dependent variable) }\end{array}$ & -18 & & & \\
CPA score (categories also & & 5.4 & -6.3 & 4.97 \\
$\quad$ modeled separately) & 30 & 50 & & \\
Performance change (unpublicized) & -47.00 & 128.20 & 15.52 & 30.29 \\
Council Tax change (£) & -55 & 368 & 161.06 & 70.33 \\
Claimant rate change (percent) & -2 & 0.70 & -0.59 & 0.65 \\
National newspaper reporting & & & & \\
$\quad$ (net positive stories score) & -2 & 4 & 0.02 & 0.57 \\
\hline
\end{tabular}

\section{REFERENCES}

Aidt, T. S. 2000. Economic voting and information. Electoral Studies 19:349-62.

Andrews, R., G. A. Boyne, J. Law, and R. M. Walker. 2005. External constraints on local service standards: The case of Comprehensive Performance Assessment in English local government. Public Administration 83:639-56.

Audit Commission. 2002. The final CPA assessment framework for singe tier and county councils. London: The Audit Commission. 
Boyne, G. 1998. Public choice theory and local government. New York: St Martins Press.

Broadbent, J. 2003. Comprehensive Performance Assessment: The crock of gold at the end of the rainbow? Public Money and Management 23:5-7.

Butler, D., A. Adonis, and A. Travers. 1994. Failure in British government. Oxford: Oxford Univ. Press.

Cabinet Office. 1999. Modernizing government. London: The Stationery Office.

Clarke, H., D. Sanders, M. Stewart, and P. Whiteley. 2004. Political choice in Britain. Oxford: Oxford Univ. Press.

Delli Carpini, M., and S. Keeter. 1996. What Americans know about politics and why it matters. Yale, CT: Yale Univ. Press.

Department for Transport Local Government and the Regions. 2001. Strong local leadership-quality public services. London: The Stationary Office.

der Brug, W., C. van der Eijk, and M. Franklin. 2007. The economy and the vote: Effects of economic conditions on vote preferences and election outcomes in fifteen countries. Oxford: Oxford Univ. Press.

Downs, A. 1957. An economic theory of democracy. New York: Harper and Row.

Franklin, B., and D. Murphy. 1998. Changing times: Local newspapers, technology and markets'. In Local journalism in context, ed. B. Franklin and D. Murphy, 7-23. London: Routledge.

Gibson, J. 1988. Rate increases and local elections: A different approach and a different conclusion. Policy and Politics 16:197-208.

- 1994. Voter reaction to tax change: The case of the poll tax. Applied Economics 26:877-84.

Glaser, M., and B. W. Hildreth. 1996. A profile of discontinuity between citizen demand and willingness to pay taxes: Comprehensive planning for park and recreation investment. Public Budgeting and Finance 16 (4): 96-113.

Hall, J., and I. Preston. 2000. Tax price effects on attitudes to hypothecated tax increases. Journal of Public Economics 75:417-38.

Hood, C. C., O. James, B. G. Peters, and C. W. Scott, eds. 2004. Controlling modern government. Cheltenham, UK: Edward Elgar.

Hood, C. C., C. W. Scott, O. James, G. W. Jones, and T. Travers. 1999. Regulation inside government: Waste watchers, quality police and sleazebusters. Oxford: Oxford Univ. Press.

Iyengar, S. 1987. Television news and citizens' expectations of national affairs. American Political Science Review 81:815-32.

Jacobson, G. 1990. The electoral origins of divided government: Competition in house elections 19461988. Boulder, CO: Westview.

James, O. 2003. The executive agency revolution in Whitehall: Public interest versus bureau-shaping perspectives. Basingstoke, UK: Palgrave Macmillan.

. 2004. The UK core executive's use of Public Service Agreements as a tool of governance. Public Administration 82:397-418.

John, P., K. Dowding, and S. Biggs. 1995. Residential mobility in London: A micro test of the behavioural assumptions of the Tiebout model. British Journal of Political Science 25:379-97.

Jones, D., and M. McDermott. 2004. The responsible party government model in House and Senate elections. American Journal of Political Science 48:1-12

Key, V. O. 1966. The responsible electorate: Rationality in presidential voting 1936-1960. New York: Vintage Books.

Kramer, G. 1971. Short-term fluctuations in U.S. voting behavior. American Political Science Review 65:131-43.

Lau, R. 1982. Negativity in political perception. Political Behavior 4:353-78.

. 1985. Two explanations for negativity effects in political behaviour. American Journal of Political Science 29:119-38.

Lewis-Beck, M. S., and M. Paldam. 2000. Economic voting: An introduction. Electoral Studies 19:113-21.

Lowry, R., J. Alt, and K. Feree. 1998. Fiscal policy outcomes and electoral accountability in the American state. American Political Science Review 92:759-74.

Lupia, A., and M. D. McCubbins. 1998. The democratic dilemma: Can citizens learn what they need to know? Cambridge: Cambridge Univ. Press. 
Lyons, W. E., and D. Lowery. 1989. Citizen responses to dissatisfaction in urban communities: A partial test of a general model. The Journal of Politics 51:841-68.

MacKuen, M. B., R. S. J. Erikson, and A. Stimson. 1992. Peasants or bankers? The American electorate and the US economy. American Political Science Review 86:597-611.

Martinussen, P. 2004. Government performance and political accountability at subnational level: The electoral fate of local incumbents in Norway. Scandinavian Political Studies 27:227-59.

Melkers, J. E., and K. G. Willoughby. 1998. The state of the states: Performance based budgeting requirements in 47 out of 50 states. Public Administration Review 58:66-73.

Miller, W. L. 1988. Irrelevant elections? The quality of local democracy in Britain. Oxford: Clarendon.

Milner, H. 2002. Civic literacy. Hanover, NH: Tufts.

Moynihan, D. P. 2005. Why and how do state governments adopt and implement 'managing for results' reforms? Journal of Public Administration Research and Theory 15:219-43.

Niemi, R., H. Stanley, and R. Vogel. 1995. State economies and state taxes: Do voters hold governors accountable. American Journal of Political Science 39:936-57.

Palmer, H., and G. Whitten. 1999. The electoral impact of unexpected inflation and economic growth. British Journal of Political Science 29:623-39.

Performance and Innovation Unit. 2001. Satisfaction with public services: A discussion paper. London: Performance and Innovation Unit.

Pollitt, C., J. Birchall, and K. Putnam. 1998. Decentralising public services management. Basingstoke, UK: Macmillan.

Pollitt, C., and G. Bouckaert. 2004. Public management reform. Oxford: Oxford Univ. Press.

Radcliffe, B. 1994. Reward without punishment: Economic conditions and the vote. Political Research Quarterly 47:721-31.

Radin, B. 1998. The Government Performance and Results Act (GPRA): Hyrda-headed monster or flexible management tool? Public Administration Review 58:307-16.

Rallings, C., and M. Thrasher. 1997. Local elections in Britain. London: Routledge.

—.1999-2003. Local elections handbook. Plymouth, UK: Local Government Chronicle Elections Centre.

Rallings, C., M. Thrasher, and D. Denver. 2005. Trends in local elections in Britain 1975-2003. Local Government Studies 31:393-413.

Ranney, A. 1954. The doctrine of responsible party government: Its origin and present state. Urbana, IL: Univ. of Illinois Press.

Rosenstone, S. 1982. Economic adversity and voter turnout. American Journal of Political Science 26:25-46.

Sanders, D. 2000. The real economy and the perceived economy in popularity functions: How much do voters need to know? A study of British data 1974-97. Electoral Studies 19:275-94.

Soroka, S. 2006. Good news and bad news: Asymmetric responses to economic information. Journal of Politics 68:372-85.

Tiebout, C. M. 1956. A pure theory of local Expenditures. Journal of Political Economy 64:416-24. Tunstall, J. 1996. Newspaper power: The new national press in Britain. Oxford: Oxford Univ. Press.

Turner, D., C. Skelcher, P. Whiteman, M. Hughes, and P. Jas. 2004. Intervention or persuasion: Strategies for turnaround of poorly-performing councils. Public Money and Management 24: 217-26.

Wlezien, C. 2004. Patterns of representation: Dynamics of public preferences and public policy. Journal of Politics 66:1-20. 